\title{
Ohlašuje Hegel konec náboženství? ${ }^{1}$
}

\author{
Olga Navrátilová \\ Evangelická teologická fakulta \\ Univerzita Karlova \\ Černá 646/9,115 55 Praha 1 \\ navratilova@etf.cuni.cz
}

\begin{abstract}
Autorka si v článku klade otázku, nakolik Hegel ve své filosofii ohlašuje konec náboženství jakožto specifické formy vztahování se ke světu, a tak předjímá postupující sekularizaci západní kultury. Autorka vychází z tvrzení Terezy Matějčkové v její knize Hegelova fenomenologie světa, podle nějž je Hegelem oznamovaný konec třeba chápat nikoli ve smyslu časovém, nýbrž jakožto konec ve smyslu završení, odhalení principu, který se stává „středem“ nové perspektivy. Aniž by si autorka stati kladla za cíl mnohokrát opakovanou otázku po výkladu Hegelovy teze o konci náboženství rozhodnout, přináší argumenty jak na podporu tvrzení Terezy Matějčkové, tak také ty, které s tímto tvrzením polemizují.
\end{abstract}

Klíčová slova: Hegel, filosofie náboženství, sekularizace, Matějčková

$\mathrm{Na}$ závěr kapitoly věnované Hegelovu pochopení náboženství ve Fenomenologii ducha se Tereza Matějčková ve své velmi podnětné knize vymezuje proti rozšířenému tvrzení, že Hegel svojí filosofií vedle jiných konců ohlašuje také konec náboženství. ${ }^{2}$ Chápat Hegela jako filosofa konců je podle ní oprávněné jen tehdy, chápeme-li tento konec nikoli ve smyslu zániku či zastavení, nýbrž jako „princip, telos, z jehož perspektivy je možné žít a myslet. Ti interpreti, kteří zůstávají pouze u konce, nečiní poslední rozhodující krok - vrátit se z konce zpět do

\footnotetext{
1 Tento článek byl podpořen programem Univerzitní výzkumná centra UK č. UNCE/HUM/o16.

2 Matějčková (2018, s. 326 n.).
} 
středu.“3 To platí i pro náboženský způsob vztahování se ke světu. Ten si podržuje svoji platnost i tehdy, když je podroben pojmové reflexi, díky níž ztrácí svoji jednostrannost a nedostatečnost. Učiní-li tedy věŕící tento poslední krok a dosáhne-li „jednou absolutního vědění, objevuje v náboženství absolutní vědění a naopak v absolutním vědění náboženskou dimenzi.“4

Otázka, nakolik je Hegel myslitelem, který svojí filosofí předjímá postupující sekularizaci západní kultury, se zpravidla představuje v podobě otázky po tom, jak rozumět jeho tezi o útočišti, jež „pojem“ nabízí náboženství. To je totiž podle Hegela v jeho době z jedné strany ohrožováno nevázaným subjektivismem ve zbožném hávu a ze strany druhé osvícenskou kritikou. ${ }^{5} \mathrm{~V}$ následujícím textu nejprve představím argumenty, které se nabízejí pro tvrzení, že náboženství si u Hegela podržuje svoji oprávněnost i tváří tvář filosofii. Následně pak ukáži, že Hegelova kritika některých obsahů náboženství, jak ji lze nalézt i ve výkladu Terezy Matějčkové, může vést $\mathrm{k}$ tomu, že náboženství přichází o důvod své svébytné existence. Nebudu vycházet pouze z Fenomenologie ducha, nýbrž i z Hegelových pozdějších spisů, zejména jeho berlínských Přednášek o filosofii náboženstuí. Mým cílem není spor, který vypukl už krátce po Hegelově smrti, rozhodnout, nýbrž pouze ukázat na to, že argumenty pro tvrzení, že Hegel je filosofem konce náboženství ve smyslu jak jeho završení, tak současně i zániku, mají svoji váhu.

Jako problematické se může zdát, budu-li v následujícím textu použivat pojem náboženství takřka synonymně s pojmem křestanství a otázku po konci náboženství redukovat na otázku po konci křestanství. Tento postup je však v rámci interpretace Hegelovy filosofie (nikoli však mimo ni) oprávněn tím, že Hegel označuje křestanství za náboženství, v němž se pojem náboženství završuje, ${ }^{6}$ nebot se v něm současně završuje na rovině náboženské vývoj pojmu Boha. Otázka po konci náboženství tak u něj spadá v jedno s otázkou po konci křestanství.

\footnotetext{
3 Tamtéž, s. 326.

4 Tamtéž.

5 Srov. Hegel (1995, s. 265-270).

6 Srov. tamtéž, s. 177.
} 


\section{Provázanost figurativního a pojmového myšlení}

V úvodním paragrafu první části své Encyklopedie, tzv. Malé logiky, Hegel tvrdí, že filosofie a náboženství se dělí o týž předmět:

„Náboženství i filosofie se zabývají pravdou, a to v nejhlubším smyslu - totiž v tom, že bưh a jen bůh je pravda. Jak náboženství, tak filosofie se dále zabývají oblastí konečna, př́irodou a lidským duchem, jejich vzájemným vztahem a jejich vztahem k bohu jako ke své pravdě. Filosofie tedy může, ba musí předpokládat, že už nějak známe její předměty a že se o ně zajímáme. Musí to předpokládat již proto, že vědomí si vytvárí o předmětech představy dřive než pojmy, ba že myslící duch postupuje $\mathrm{k}$ myšlenkovému poznávání a chápání jen skrze představování a tím, že se na ně obrací.“8

Tento odstavec ve stručnosti shrnuje, jaký je podle Hegela vztah filosofie a náboženství. Předmětem jak náboženství, tak filosofie je pravda, a to nikoli jako zásvětní konstrukt (v podobě Boha, který je vičč lidskému poznání a lidskému světu ryze transcendentní, či v podobě věci o sobě, která je filosofickým vyjádřením téže transcendence), nýbrž jako pravda našemu poznání imanentní, která vede naše tázání a myšlení. Musí být dosažitelná, protože je vždy již přítomná, byt do určité míry zastř̌eně do té doby, než nám spekulativní filosofie odhalí její povahu. Náboženství, které by si představovalo Boha jako zcela nedosažitelného a nepoznatelného, by bylo v rozporu se sebou samým a se svojí praxí - na jednu stranu je náboženství $\mathrm{z}$ podstaty věci vztahem $\mathrm{k}$ Bohu, na stranu druhou by však tezí o naprosté Boží skrytosti tento vztah popíralo. Totéž pak platí i pro filosofii a její vztah k pravdě: Kdyby to filosofie myslela se skepsí opravdu vážně, veškeré její tázání a myšlení by muselo umlknout. Předmětem náboženství a filosofie pak není Bůh či pravda představovaná tak, jako by byla izolovaná od světa přírody či lidského ducha, bezprostředně přístupná pouze duchovnímu názoru či

7 V tomto oddíle vycházím ze svého textu v knize Stát a náboženství v Hegelově filosofii (2015, s. 184-189) a některé jeho části přejímám.

8 Hegel (1992a, § 1). 
ryzímu citu (což jsou jen dvě stránky téhož), nýbrž Bůh či pravda, která se dává na pozadí světa a ve vztahu k němu, která tento svět umožňuje poznávat, pochopit a orientovat se v něm a v jejímž světle rozumíme př́rodě i lidskému duchu.

Rozdíl mezi náboženstvím a filosofií tak nespočívá v jejich předmětu, nýbrž ve způsobu, jak se $\mathrm{k}$ tomuto předmětu vztahují. Jakkoli je náboženství stejným projevem lidského myšlení jako filosofie, omezuje se na myšlení figurativní, spjaté s představami, obrazy, které jsou doprovázeny citem. Filosofie pak tento zpo̊sob myšlení překračuje, když zaměřuje prostřednictvím reflexe svůj pohled právě na myšlení samo: „Ovšem jedna věc je mít takovéto myšlením určené a prostoupené city a představy, a druhá věc mít myšlenky o nich." 9 Figurativní myšlení, které je nutně zatíženo nahodilostí, není plně právo absolutnímu obsahu, jejž se v náboženství snaží vyjádřit. Proto pod tlakem svého obsahu, jenž hledá sobě přiměřený výraz, se náboženství samo překračuje do filosofie, která tento obsah zbavuje vší omezenosti a nahodilosti a ukazuje jej prostřednictvím pojmové reflexe jako nutný. Náboženství se tak završuje ve spekulativní filosofii.

Tyto úvahy Hegel nečiní ve vzduchoprázdnu, nýbrž zasahuje je do vztahu k duchovní situaci své doby. V ní, jak se zdá, stojí náboženství, především ve své tradiční a institucionalizované podobě, a osvícenská filosofie proti sobě. Jejich vzájemný boj vychází z toho, že jak náboženství, tak filosofie nemají jasno o své vlastní povaze. Obě spolu bojují ve jménu pravdy, již si však představují jako transcendentní. Pokud se náboženství nepropadne do naprosté subjektivity individuálního prožitku, jako je tomu v pietismu, je jeho výhodou to, že uchovává obsah v podobě církevního učení. Ten se však představuje pouze jako tradovaný, podepřený vnější autoritou, a proto vůči němu osvícenská filosofie snadno uplatní svoji zbraň, jíž je právě zpochybnění tradice a autority prostřednictvím myšlení. Současně však bojuje tato filosofie vůči náboženství ve jménu pravdy, kterou popírá, když se omezuje pouze na oblast konečnosti. Hegel proto náboženskému obsahu nabízí „útěk do pojmu“"10 ve své vlastní filosofii, nebot’ mu chce dostát a současně má

9 Tamtéž, § 2 pozn. (kurziva Hegel).

10 Hegel (1995, s. 267). 
činit zadost nárokům, které na způsob, jakým je tento obsah předkládán, klade člověk vyučený ve škole osvícenské kritiky. Filosofie je tak podle Hegela práva nejen náboženství, nýbrž i sama sebe tehdy, když bere jeho obsah vážně; náboženství je pak právo samo sobě, když bere vážně svůj obsah a umožní mu toto útočiště v pojmu přijmout.

Vzhledem k tomu, že myšlení, má-li mít nějaký obsah, se samo k sobě dostává oklikou, („vědomí si o předmětech vytváří představy dřive než pojmy“"11), předchází náboženský vztah ke světu a k pravdě pojmovému uchopení tohoto vztahu. ${ }^{12}$ Toto východisko je však východiskem v tom smyslu, že je v postupu myšlení jako východisko překonáváno, když danost obsahu, na niž je myšlení původně odkázáno, nebot' bez tohoto obsahu by bylo myšlením prázdným, je reflexí myšlení na sebe sama převedena na nutnost. Skutečnost, že představa dodává reflexivnímu myšlení obsah, je důvod, proč musíme, jak upozorňuje Paul Ricœur ve svém článku věnovaném významu představy $\mathrm{v}$ Hegelově filosofii náboženství, chápat vztah mezi náboženstvím a spekulativní filosofií jako vztah vzájemné odkázanosti. Ekvivalenci mezi myšlením obrazným a myšlením spekulativním je proto

„...možno vést ve dvou směrech a ne pouze ve prospěch myšlení spekulativního. V tomto smyslu mohli Feuerbach a Marx s jistým oprávněním tvrdit, že filosofie je náboženstvím převedeným na myšlení. Správně si všimli toho, že zánik náboženství by s sebou přinesl zánik filosofie jakožto spekulativního přepisu náboženství. “" ${ }^{13}$

Shodně s Terezou Matějčkovou ${ }^{14}$ pak Ricœur tvrdí, že v závěru jak Fenomenologie ducha, tak podle Ricœura i Encyklopedie dochází pouze

11 Hegel (1992a, § 1).

12 V poznámce k § 2 Malé logiky Hegel ironicky poznamenává, že trvat na tom, že teprve filosofický náhled způsobuje přesvědčení „o věčném a pravdě“ (např. prostřednictvím důkazů Boží existence), se rovná „názoru, že nemůžeme jíst, dokud jsme se neseznámili s chemickými, botanickými či zoologickými charakteristikami potravin, a musíme tedy počkat s trávením, až si odbudeme studium anatomie a fyziologie“. (Hegel, 1992a, § 2, pozn.).

13 Ricœur (1985, s. 185-206, s. 204).

14 Srov. Matějčková (2018, s. 328). 
$\mathrm{k}$ rekapitulaci celého předchozího procesu. ${ }^{15} \mathrm{~V}$ tomto zpětném pohledu je patrné, že to bylo myšlení, které neslo všechny předchozí podoby ducha a projevovalo se v nich. Absolutní vědění tak není dalším rozšiřrením vědění, ale věděním, které odhaluje inteligibilní charakter veškerých představ, forem vědomí i světů, jež si duch vytváří. Spekulativní myšlení není ničím, co by bylo vůči figurativnímu myšlení vnějším, nýbrž je tím, co podněcuje vnitřní dynamiku figurativního myšlení samého a uvádí představy do pohybu a vzájemných vztahů. ${ }^{16}$ Ricœur proto tvrdí, že přinejmenším v pozdní fázi svého myšlení si Hegel uvědomoval, že filosofie má budoucnost pouze tehdy, je-li uchováno i myšlení obrazné. Ricœur z toho vyvozuje, že se proto:

„....stává možným reinterpretovat hermeneutiku náboženského myšlení jako nekonečný proces, díky kterému se reprezentativní myšlení a spekulativní myšlení nepřestávají vzájemně podněcovat. Tento druhý návrh nás vrací zpět k vnitřní dynamice, která nepřestává vést figurativní myšlení k myšlení spekulativnímu, aniž by byly jakkoli popřeny narativní a symbolické rysy figurativního modu. ${ }^{{ }^{17}}$

Podle této interpretace by si tak náboženství uchovávalo svůj význam tváří tvář absolutnímu vědění, a to nikoli pouze jako jeho vnitřní rozměr, jímž určitě je, nýbrž také jako svébytná forma myšlení, z nějž myšlení spekulativní čerpá svůj obsah, i když ji zároveň neustále překračuje.

Obdobným směrem jde i argumentace Terezy Matějčkové. Je špatným pochopením Hegelovy filosofie, vưči němuž se Hegel sám brání, pokud bychom si mysleli, že pojmové uchopení předchozích podob vědomí, které vždy nějak vycházejí z diference mezi myšlením a bytím, znamená jejich zánik: „Smyslové bytí, na kterém by si ,smlslo“ myšlení, by přestalo existovat.“" 18 To platí i pro náboženství: „Náboženství se nezavršuje tím, že je Hegel převede na kategorie myšlení. Místo toho Hegel ukazuje,

\footnotetext{
15 Srov. Ricœur (1985, s. 204).

16 Tamtéž, s. 188.

17 Tamtéž, s. 205.

18 Matějčková (2018, s. 326).
} 
jak lze pojmově explikovat základní náboženské kategorie.“"19 Hegel tak vlastně dává, je možno dodat, náboženství zapravdu, když ukazuje, že tyto základní náboženské kategorie mají racionální obsah a odhalují strukturu skutečnosti postižitelnou myšlením.

\section{Problém transcendence}

Nelze však zastř́it, že způsob, jímž Hegel provádí tento převod představy na pojem, má i svoji „destruktivní“ stránku. Převádění na pojem znamená totiž současně vždy také tř́dění a při tomto třídění berou určité stránky náboženství za své. Kř̌stanství, v němž pojem náboženství nachází podle Hegela svůj dokonalý výraz, přichází v Hegelově interpretaci o dva význačné rysy: (1) pochopení Boha nejen jako Boha, který se bytostně zjevuje, aletakéjako Boha, kterýsiiv tomtozjevováníuchovávásvéčlověku nepřistupné nitro, tedy pochopení Boha jako také transcendentního, a s tím související (2) eschatologický rozměr křestanského náboženství. Oběma těmto rysům se budu věnovat v následujících dvou oddílech. Oba mají svioj základ v tom, co podle Hegela konstituuje svébytnou povahu náboženství, totiž ve spojení náboženských obsahů s formou „představy“, jež je na jednu stranu způsobem, jak náboženské vědomí rozvijí v předmětném modu obsah svého vědění, jež však současně toto vědomí od jeho obsahu odcizuje.

Hegelův výklad křestanství je důsledným domýšlením teologie kř́ǐze, kterou hojně rozvíjela zejména luterská tradice, z níž Hegel vychází. $\mathrm{Na}$ kř́ži pro Hegela neumírá pouze Bůh, který na sebe vzal podobu jednotlivce, člověka Ježíše Krista, ${ }^{20}$ ale současně Bůh představovaný jakožto abstraktně pojatá božská bytnost či bytost (Wesen): ${ }^{21}$ božská bytost, která spočívá $\mathrm{v}$ sobě samé mimo tento svět a mimo mé vlastní já. V této abstraktní božské bytosti člověk současně nachází svoji oporu, nebot' jakkoli je Bůh představován jako transcendentní, vědomí se vůči němu vztahuje jako k substanci, z níž získává své bytí a svoji pevnost. Právě to je postojem neštastného vědomí, vědomí vnitřně rozdvojeného,

19 Tamtéž, s. 327.

20 Srov. Hegel (1960, s. 472).

21 Srov. tamtéž, s. 473. 
pro nějž je to, že Boha klade zcela mimo sebe, zdrojem jak neštěstí (takového Boha nelze nikdy dosáhnout), tak útěchy (o takového Boha je možno se „opřít“). Bolest ze smrti Boha je bolestí ze ztráty této opory, z rozplynutí veškeré předmětnosti; je bolestí, v níž se vědomí stahuje do sebe sama a tone $\mathrm{v}$ „hloubi noci, kterou je já = já, noci, jež mimo sebe již nic nerozeznává a nevi'. ${ }^{22} \mathrm{~V}$ hlubině této noci ale objevuje světlo: Namísto toho, aby vědomí hledalo Boha mimo sebe a snažilo se při vědomí své nepodstatnosti a konečnosti najít v jeho abstraktní absolutnosti oporu, objevuje Boha v sobě. V sobě jej však objevuje jen tak, že se současně samo sebe vzdává, nebot’ lpění na sobě, jež je jen druhou stranou fixace vědomí na představu Boha jako na něm nezávislé substance, je zdrojem jeho neštěstí. Spolu s Kristem původně neštastné vědomí odumírá své individualizované a izolované zvláštnosti a takto samo sebe nachází spolu s druhým a ve druhém jako účastné na jednom a témže duchu: Bohu, který je přítomen uprostřed své obce. Tím současně Bůh představovaný jako substance nabývá sebevědomí, stává se subjektem, ve své obci se vztahuje sám k sobě, stejně jako se jakožto subjekt konstituuje i vědomí samo.

V Hegelově interpretaci je tak Bůh Bohem, který se bytostně zjevuje, který si neponechává nic pro sebe. Skutečnost, že si ho křestanská církev představuje jako v určitém ohledu v sebe uzavřeného a že pohyb, v němž se Bůh v ní samé vztahuje k sobě, chápe jako pohyb, který probíhá mimo ni, je důsledkem její vázanosti na figurativní, představující myšlení. Vinou tohoto způsobu myšlení zůstává její představa Boha zatížena předmětností, kterou je třeba překonat. Odlišení imanentní a ekonomické Trojice, pokud bychom použili těchto novodobých teologických pojmů rozlišujících dynamický vztah božských osob v Bohu samém a v Bohu, jak se zjevuje v dějinách, ${ }^{23}$ si v Hegelově výkladu podržuje sice smysl, ale jen proto, že duch, který sám k sobě přišel prostřednictvím člověka a dějin, si současně uvědomuje svoji věčnou strukturu jako předpoklad tohoto dějinného pohybu a veškerého svého zjevování.

\section{Tamtéž.}

$23 \mathrm{~K}$ velmi hrubému nárysu diskuse ohledně vztahu těchto dvou pojmů, která byla v novodobé, zejména evangelické teologii určena do velké míry právě Hegelem, viz Pohlmann (2002, s. 134138). 
Přinejmenším ve Fenomenologii ducha je tato zatíženost představou chápána jako něco, co znemožňuje křestanské obci, aby si plně uvědomila, čím sama je. Přetrvává v ní rozpor mezi tím, co sama koná, a tím, jak si rozumí: „Obec nemá také vědomí o tom, čím jest; obec je duchovní sebevědomí, které si není předmětem jako duchovní sebevědomí." ${ }^{24}$ Také proces smírení je představován jako něco, co je člověku vnější. Pozice neštastného vědomí tím nebyla ještě plně překonána, zásvětí, do nějž se člověk utíká, si podržuje svoji platnost vůči tomuto světu. ${ }^{25}$ V Přednáškách o filosofii náboženství Hegel prismatem tohoto napětí mezi obsahem křestanské zvěsti a formou, jejímž prostřednictvím se tento obsah podává, vykládá dějiny křestanství od jeho počátků až po svoji současnost. Ta je dobou krize křestanství, v níž se na půdě křestanské kultury znovu opakují rozpory, které charakterizovaly dobu před jeho vznikem a z nichž křestanství najde cestu ven jen tehdy, když za pomoci spekulativní filosofie konečně dospěje k pochopení sebe sama. V tomto smyslu se křestanství ve filosofii skutečně završuje.

Co však znamená tato filosofická interpretace, jíž se má křestanství zbavit reziduí neštastného vědomí, pro křestanské sebepochopení, jak se vyjadřuje v kultu a osobní zbožnosti? Při veškeré diverzitě křest’anské náboženské praxe se dá říci, že tato vychází z vědomí napětí mezi Boží imanencí a Boží transcendencí. Bůh se zjevuje na pozadí své skrytosti. S představou Boží transcendence souvisí i představa, že Bůh nepotřebuje svět, aby se sám k sobě vztahoval a došel k vědomí sebe, jakkoli otázky po vztahu Boha a světa právě v křestanství s jeho zvěstí o Boží inkarnaci a kříži znamenají pro tuto představu trvalou výzvu. Ke křestanskému kultu i osobní zbožnosti patří také modlitba, při níž jednotlivý věřící i celé shromáždění přistupují $\mathrm{k}$ Bohu analogicky vůči mezilidským vztahům jako k druhému, který může „slyšet“ a „odpovídat“, jakkoli v modlitbě samé naráží tato analogie na svoje meze a může se v určitém ohledu ukazovat jako problematická. Ve vztahu $\mathrm{k}$ Bohu si věŕící pochopitelně uvědomuje omezenost a podmíněnost veškerých svých představ, katafáze i apofáze jdou ve zbožnosti nejen křestanské ruku $\mathrm{v}$ ruce.

24 Hegel (1960, s. 474).

25 Srov. tamtéž. 
Náboženské vědomí tak žije $\mathrm{z}$ dynamiky mezi Boží imanencí a transcendencí, pravdou zjevnou a skrytou, mezi Bohem, který je duchem př́tomným ve své obci, a Bohem, $\mathrm{k}$ němuž se tato obec modlí, Bohem, který se vydává, i Bohem, který si podržuje svoji nepř́stupnou velebnost. Tato dynamika vychází ze skutečnosti, že oba póly vztahu jsou udržovány oddělené, jakkoli jsou na sebe současně odkázané, a tato oddělenost má základ v tom, že náboženské vědomí se pohybuje v modu představujícího myšlení. Vzhledem $\mathrm{k}$ tomu, že forma představy je podle Hegela konstitutivním prvkem náboženství, filosofický výklad, který by tuto diferenci popřel, by byl pro náboženství destruktivní. Filosofie by pak nahradila nejen teologii, ale i náboženství. Naproti tomu filosofický výklad, který by explikoval vzájemnou zprostředkovanost obou těchto pólů (jíž si náboženské vědomí nemusí být plně vědomo, byt ji samo vlastně vyjadřuje), aniž by rušil napětí mezi nimi, by podržel náboženství $\mathrm{v}$ jeho svébytnosti.

Musím se přiznat, že mi není zcela jasné, který z těchto dvou kroků Hegel činí. Na jedné straně jeho kritika představy Boží nepoznatelnosti, chápání formy představy jako omezení, jež brání náboženskému vědomí, aby pochopilo samo sebe, jeho pojem Boha, který sám k sobě přichází prostřednictvím světa a dějin, byt' jej s nimi zároveň nelze plně ztotožnit, by svědčila spíše pro první možnost. Na straně druhé však duch u Hegela žije z napětí a diference a filosofické uchopení neznamená, že by ostatní způsoby vztahování se člověka k sobě a ke světu ztratily svioj význam a svoji platnost, nebơ právě z nich filosofický výklad vyrůstá a bez nich by ztratil svůj obsah.

Tereza Matějčková nabízí ještě další možnost, jak nakládat s problémem transcendence u Hegela. V Ježíšově smrti a vzkříšení, jak si je přivlastňuje křestanská obec, a tím uprostřed sebe odhaluje Boha, který se zjevuje v aktu vyznání vin, odpuštění, uznání a lásky, se transcendence přesouvá „ze zásvětí do světa“. ${ }^{26}$ Nejde tak již o transcendenci Boha, nýbrž o transcendenci druhého, vưči němuž se já vzdává samo sebe, dává se druhému cele $\mathrm{k}$ dispozici, a tím samo sebe získává. Pohyb transcendence, vydání se druhému, představuje pohyb, jímž se konstituuje jak jedinečnost lidskéhojá, taklidskéspolečenství. Bůh pakneníviočitomuto pohybu něčím „třetím“, ale je právě tímto pohybem, který v sobě jak uchovává rozdílnost

26 Matějčková (2018, s. 324). 
já a ty, tak je jejich vzájemným vztahem. $\cdot{ }^{27}$ Není to již transcendence Boha, ale transcendence v Bohu, a sice transcendence ryze světská. Právě tato povaha Boha a transcendence se ukazuje v křestanském náboženství, které z Kristova kříže činí ústř̌ední bod Božího zjevení. Tímto výkladem se ale, dlužno říci, výšse popsané napětí mezi Bohem, jenž je přítomen uprostřed slavící obce, a Bohem, k němuž se tato obec modlí, také ztrácí, a je proto otázka, jaký smysl si podržuje vlastní náboženské konání jednotlivého vědomí i celé obce ( $k$ tomu více v posledním oddílu).

\section{Konec klamných nadějí}

Představu Boží transcendence podrobuje Hegel kritice i s ohledem na otázku vztahu Boha ke světu v jeho časovém a dějinném rozměru. Radikalita myšlenky Božího vtělení, jež se plně ukazuje v představě Boží smrti na kř̌̌zii, vydává Boha času a dějinám. Proto křestanské obci, která ještě ne zcela pochopila své vlastní konání a zůstává v zajetí představ, jež nejsou zprostředkovány pojmem, se ukazuje smíření jako „něco vzdáleného, jako vzdálená budoucnost, tak jako smírení dokonané druhou osobou jeví se vzdáleným minulosti“ ${ }^{28}$ a nerozpoznává proto, že k němu dochází v jejím středu tady a ted'. Tato orientace jak na minulost chápanou jako oddělenou od současnosti, tak na budoucnost, jež má teprve přinést spásu, je totožná s orientací na zásvětí, do něhož se utíká neštastné vědomí, které není schopno smíriti se $\mathrm{s}$ tímto světem a rozpoznat, že právě ten je místem, v němž uprostřed bolesti a při setkání člověka s vlastní konečností je jedině přítomen Bůh.

Spolu s touto kritikou představy smíření jako časově vzdáleného se proměňuje i obsah křestanské naděje. Závěrečné články tradičních křestanských kréd, které vzkřriššení a soud kladou do budoucnosti, nabývají výsostně přítomnostní význam, jejž ostatně křest’anství vždy obsahovalo. ${ }^{29}$ Očekávání, že Bůh „bude všecko ve všem“30, se u Hegela proměnilo v náhled, že Bůh je všecko ve všem. To, co brání takto

\footnotetext{
27 Tamtéž, s. 312.

28 Hegel (1960, s. 474).

29 Srov. např. J 3,18.

30 Viz $1 \mathrm{~K}$ 15,28.
} 
rozumět př́tomnosti, je špatné pochopení toho, co znamená smíření. Jak upozorňuje Tereza Matějčková, smíření podle Hegela není zahlazením protikladů, vymizením smrti, utrpení a bolesti. ${ }^{31}$ Mylné pochopení smíření vede k zastření skutečnosti, že utrpení, bolest a rozpoznání vlastní konečnosti mají „transformativní funkci“32 a jejich význam je bytostně duchovní. Duch je duchem právě proto, že v sobě unese protiklady, a právě v tomto unesení protikladů spočívá smíření.

K tomuto tématu se Hegel vrací v Přednáškách ke světovým dějinám. V křestanství je účelem a cílem života jednotlivce jeho posvěcení, stejně jako je účelem a cílem př́rody a dějin oslavení Boha. Bylo by ale mylné chápat obojí jako pouhý výsledek, $\mathrm{k}$ němuž se teprve směřuje, stav, $\mathrm{k}$ němuž dojde $\mathrm{v}$ budoucnosti a vůči němuž by lidský život i dějiny byly pouhými prostředky. Je to právě tento proces sám, v němž k posvěcení člověka i oslavě Boha dochází. Je proto třeba, aby člověk pochopil, že Bůh je absolutnem, které se trvale zjevuje $\mathrm{v}$ př́rodě a $\mathrm{v}$ dějinách, a tímto poznáním aby Boha oslavil, a aby pochopil, že on sám je součástí tohoto pohybu Božího (sebe)oslavení, a právě tím je posvěcován. Nikoli pokračování individuální existence přesazené do zásvětí, nýbrž tento podíl na životě ducha, který sám sebe rozvijí a poznává, je jedinou a pravou formou spásy a nesmrtelnosti, která se jednotlivci nabízí. ${ }^{33}$ Zaujetí postoje, kterým člověk přijímá svět tak, jak je, a neutíká ze svého místa $\mathrm{v}$ něm, je projevem dospělého muže, který nepropadá klamným nadějím, jež mají pro současnost zpravidla ničivé účinky. ${ }^{34}$ Tento postoj pak ovšem není pro Hegela postojem rezignace. Naopak, není-li budoucnost předmětem ani nadměrného očekávání, ani strachu, je vůči ní člověk svobodný, a budoucnost se mu tak dává jako prostor pro uplatňování této svobody i při všech omezeních, jimž je podroben. Tímto směrem jde i výklad Terezy Matějčkové, která upozorňuje, že podstatným rysem smíření se světem je přijetí světa v jeho časovosti. Namísto naděje spojené $\mathrm{s}$ očekáváním dobrého konce nastupuje odvaha, překonání strachu: „Člověk [...] musí být ochoten [...] riskovat.

31 Srov. Matějčková (2018, s. 320 n.).

32 Tamtéž, s. 321.

33 Srov. Hegel (1994, s. 181 n).

34 Srov. Hegel (1992a, § 234, dod.). 
V Hegelově náboženském slovníku to znamená, že musí být schopen obětovat dnešek pro zítřek." Přitom Hegel „nemíní nikomu garantovat, že se cokoli kdykoli ,vyplatí" a že by něco mohlo dobře dopadnout“. ${ }^{35}$

Bůh zde tak ztrácí svoji transcendenci vůči dějinám. Není už pánem nad dějinami, ale vydává se jim. Mohli bychom namítnout, že podstatným prvkem do budoucna zaměřené naděje, jak ji formulují poslední články apoštolského i nicejsko-cařihradského vyznání, není pouze očekávání smiřující budoucnosti pro mne, ale také pro ostatní. Usmiřující „ano“, které je vyznáním vlastních vin, vydáním se druhému a přijetím vlastních hranic, usmiřuje ty, kdo je vyslovují. Jak se to však má s těmi, kdo k tomu nedostali šanci? Je rozdíl mezi obětí, kterou člověk sám činí, když se vydává druhému, a obětí, kterou se člověk stává. Poučení z chyb, duchovní růst vycházející z vlastního selhání, ${ }^{36}$ transformace prostřednictvím bolesti se nabízí jen těm, kdo př̌žili. Ti ostatní zůstávají nesmířeni, stejně jako zůstává nesmířena vina těch, kteří se na nich provinili. Zde bychom však mohli v Hegelově duchu argumentovat, že i jim se může dostat jakési formy smíření, byt' ryze světské. Jediná podoba smíření, jež se těmto obětem nabízí, je ta, že budou připomínány, že jim bude zpětně přiznáno jejich právo či že jim bude pohřbem vrácena jejich lidská důstojnost. Smíření, které je zároveň soudem, je tak odebráno z rukou Božích, kam jej klade křestanská naděje, a je předáno do rukou čistě lidských, v nichž zůstává zatíženo vší nahodilostí, podmíněností a zapomnětlivostí, jež se s tím pojí. Soud, který obě starokřestanská vyznání kladou na konec dějin a který je soudem pro každého člověka, chápe totiž Hegel jako soud, který je dějinám imanentní. Byt' při tomto soudu ustupuje ohled na jednotlivce poněkud do pozadí a souzeny jsou celé státy a kulturní epochy, jejichž konečnost takový soud vyjevuje, a tak jim upírá jakékoli absolutizující nároky, ${ }^{37}$ bylo by zkreslením chápat Hegelovo ztotožnění světových dějin se soudem nad světem jako jeho postavení se na stranu vítězící moci ${ }^{38}$ (u Hegela to často právě není moc, která vítězí, a zdánliví vítězové dějin se záhy ukazují jako poražení).

35 Matějčková (2018, s. 335).

36 Srov. tamtéž, s. 324.

37 Srov. Hegel (1970, § 548).

38 Tak např. Schnädelbach (200o, s. 351-353). 


\section{Ohlašuje Hegel konec náboženství?}

Nelze než souhlasit s Terezou Matějčkovou, že pozice, z níž Hegel pohlíží na náboženství, je konec ve smyslu telos. Současně však platí, že rozpoznání tohoto účelu znamená proměnu náboženství, a jde nyní o to, co tato proměna znamená. Na půdě křestanství a z jeho vlastních zdrojů Hegel provádí kritiku, která ústí do odmítnutí představy takové Boží transcendence, která by umožnila chápat Boha jako někoho „třetího“ (byt současně přítomného $\mathrm{v}$ aktu usmíření), stejně jako by umožnila představovat si ho jako pána nad dějinami, k němuž by se mohla upínat naděje věřících vydaných dějinám. Taková představa Boží transcendence, která je v náboženství v dynamickém napětí s představou Boží imanence, vyplývá z představující formy myšlení. Jenže právě ta určuje svébytnost náboženství vůči filosofii. Vzdá-li se náboženství těchto Hegelem kritizovaných obsahů, zůstane ještě náboženstvím? Je u Hegela vztah mezi představou a pojmem přinejmenším v tomto ohledu skutečně tak obousměrný, jak tomu chce Paul Ricœur ${ }^{39}$ a jak je tomu i ve výkladu Terezy Matějčkové?

Věříí vědomí, které dosáhne absolutního vědění ${ }^{40}$ a rozpozná, že smyslem náboženských kategorií je vyjádřit ontologickou strukturu jej samého i světa, $\mathrm{k}$ němuž se bytostně vztahuje, ${ }^{41}$ se již nemůže vrátit $\mathrm{k}$ náboženským představám $\mathrm{v}$ podobě, $\mathrm{v}$ jaké se $\mathrm{k}$ nim vztahovalo dřive. Jeho představy přišly o svoji bezprostřednost a ono samo o svoji naivitu..$^{42}$ To se ukazuje zejména na kultu. Hegel ve své filosofii náboženství

39 Obousměrný je zejména u Paula Ricœura v jeho konceptu „druhé naivity“, jež je pokusem o odpověd’ na otázku, kterou nastolil právě Hegel, stejně jako filosofií a teologií 20. století prováděný demytologizující výklad náboženských symbolů. Tato „druhá naivita“ je výsledkem hermeneutiky náboženských symbolů a s ní spojeného pohybu v hermeneutickém kruhu víry a porozumění (který v mnohém připomíná Hegelův pohyb od jistoty k pravdě). Proces interpretace dává symbolům, ve vztahu k nimž jsme již ztratili bezprostřednost porozumění, znovu promlouvat a umožňuje tak obnovit jejich bezprostřednost na nové rovině (viz Ricœur 2011, s. 454 n.).

40 Srov. Matějčková (2018, s. 327).

41 Srov. tamtéž, 330 n.

42 To pochopitelně neznamená, že by křestanské dějiny neprovázela již od jejich počátků pojmová reflexe. Křestanství v sobě samém obsahuje požadavek, aby byl jeho obsah vyjádřen myšlením. (srov. např. Hegel $(1974$, s. 76)). Toto myšlení se však ještě ne plně zbavilo figurativnosti svého východiska (a to ani v případě, že se k tomuto obsahu staví tak, že jej takřka všechen popírá, jako je tomu podle Hegela v př́ípadě moderní teologie a jejího odmítnutí dogmatu). 
rozpoznává, že náboženství není jen teoretickým náhledem, ale bytostně k němu patří i kult. ${ }^{43}$ Lze říci, že právě z kultického jednání náboženství žije. Ačkoli se na tomto kultu konaném $\mathrm{v}$ určitém náboženském společenství mohou podílet lidé s různou mírou intelektuálního odstupu, vyrůstá tento kult svým zpo̊sobem z bezprostřednosti představ (to pochopitelně neznamená, že by tyto představy nevedly k přemýšlení, ale to se k nim vrací jako ke svému zdroji). Ke křestanskému kultu bytostně patří, že se v něm slavící společenství vztahuje k Bohu jako k někomu „jinému“, jakkoli je tento „jiný“ současně duchem, který toto společenství sjednocuje se sebou a tento vztah vůbec umožňuje. K takovému Bohu se obec i jednotlivý věřící modlí. Své viny vyznává nejen druhým, ale i jemu, z jeho rukou právě tak přjímá i odpuštění, jemu se odevzdává ve chvíli svého umírání a jemu svěřuje všechny své mrtvé. Jaký smysl by mělo takové počínání pro toho, kdo nahlédne, že Boží transcendence je ryze světská a Boha si jako takového „jiného“ či „tř̌etího“ nelze představovat?

Zdá se mi, že i zde platí Hegelovo rozpoznání, že filosofie přichází vždy až jako poslední a že ,jestliže filosofie maluje svou šed’ šedě, pak zestárla jedna podoba života a šedou šedí ji nelze omladit, nýbrž jen poznat“. 44 Ty podoby bezprostřednosti, jež filosofická reflexe podrobuje svému zkoumání, přecházejí do zvnitřňující vzpomínky, která se v Hegelově filosofii dějin stává základem pro vznik nové podoby bezprostřednosti. Tento „mechanismus“ poháněl i vývoj jednotlivých náboženství. $\mathrm{V}$ případě křestanství je však potíž v tom, že se v něm podle Hegela vývoj pojmu náboženství završuje. Přichází-li tedy křestanství ve své stávající podobě, co se obsahu jeho představ i jeho kultu týče, o svoji bezprostřednost, měla by se rodit nějaká jiná podoba bezprostřednosti. Lze se ptát, bude-li i ona náboženstvím, je-li jeho vývoj pro Hegela završen.

Je snad možno nakonec říci, že nejednoznačnost odpovědi na otázku po „konci náboženstvi“ u Hegela odpovídá tomu, že sám stojí svojí filosofií na rozhraní. Jeho filosofie čerpá z křest’anského dědictví a je skutečně velkolepým a hlubokým filosofickým výkladem křestanského učení, ale snad právě tím „maluje svou šed’ šedě“. Hegel jako by předznačoval

43 Srov. Hegel (1993, s. 330-338).

44 Hegel (1992b, s. 32). 
postoj, který bojuje o převahu v západním světě, kde člověk postupně přejímá vládu nad světem namísto Boha, a to po prvních tragických nezdarech už méně triumfálně, s vědomím vší své omylnosti, křehkosti a závislosti, a spolu s přijetím své konečnosti přijímá tento svět jako jediné místo, $v$ němž je mu kdy dáno žít. $V$ tomto duchu se nese, zdá se mi, i výklad Terezy Matějčkové: Hegel v její interpretaci tak sice nahlíží náboženství z jeho konce ve smyslu účelu, ale tímto účelem je svět, jak tomu napovídá i její provokativní nahrazení pojmu „ducha“ z názvu Hegelova spisu za pojem „světa“.

\section{Literatura}

Bible: písmo svaté Starého a Nového zákona: český ekumenický překlad (1993). Praha.

Hegel, G. W. F. (1960): Fenomenologie ducha. Nakladatelství Československé akademie věd, Praha.

Hegel, G. W. F. (1970): Enzyklopädie der philosophischen Wissenschaften, III. Suhrkamp, Frankfurt am Main.

Hegel, G. W. F. (1974): Dějiny filosofie III. Academia, Praha.

Hegel, G. W. F. (1992a): Malá logika. Svoboda, Praha.

Hegel, G. W. F. (1992b): Základy filosofie práva. Academia, Praha.

Hegel, G. W. F. (1993): Vorlesungen über die Philosophie der Religion. Teil 1. Der Begriff der Religion. Felix Meiner, Hamburg.

Hegel, G. W. F. (1994): Vorlesungen über die Philosophie der Weltgeschichte. Band I. Die Vernunft in der Geschichte. Felix Meiner, Hamburg.

Hegel, G. W. F. (1995): Vorlesungen über die Philosophie der Religion. Teil 3. Die vollendete Religion. Felix Meiner, Hamburg.

Matějčková, T. (2018): Hegelova fenomenologie světa. OIKOYMENH, Praha. 
Pohlmann, H. G. (2002): Kompendium evangelické dogmatiky. Mlýn, Jihlava.

Navrátilová, O. (2015): Stát a náboženstuí v Hegelově filosofii. OIKOYMENH, Praha

Ricœur, P. (1985): „Le status de la Vorstellung dans la philosophie hégélienne de la religion." In Qu'est-ce que Dieu? Philosophie/Theologie, Hommage à l'abbé Daniel Coppieters de Gibson, ed. H. Ackermans, Presses de l'Université Saint-Louis, Bruxelles, 1985, s. $185-206$.

Ricœur, P. (2011): Fïlosofie vůle II. OIKOYMENH, Praha.

Schnädelbach, H. (2000): Hegels praktische Philosophie. Ein Kommentar der Texte in der Reihenfolge ihrer Entstehung. Suhrkamp, Frankfurt am Main.

\begin{abstract}
Does Hegel announce the end of religion?

The article focuses on the question to what extend Hegel announces the end of religion as the specific form of the understanding of the world and thus anticipates the gradual secularization of Western culture. This question proceeds from the claim of Tereza Matějčková (from her book Hegel's Phenomenology of the World) that the "end" announced by Hegel is not to be understood in the temporal sense but in the sense of completion, i.e. as the exposure of the principle that becomes the "center" of a new perspective. It is not author's ambition to adjudicate this old controversy regarding the interpretation of Hegel's claim about the end of religion; she merely brings arguments supporting the interpretation of Tereza Matějčková as well as those opposing it.
\end{abstract}

Key words: Hegel, Philosophy of Religion, Secularization, Matějčková

Navrátilová, O. (2020): „Ohlašuje Hegel konec náboženství?“ Filosofie dnes 12 (1): 33-49. Dostupné z www.filosofiednes.ff.uhk.cz 